\title{
Chemical quality of Baru almond (Dipteryx alata oil)
}

\author{
Qualidade química do óleo da amêndoa de baru (Dipteryx alata)
}

\author{
Ana Paula Silva Siqueira ${ }^{\mathrm{I}}$ Carlos Frederico de Souza Castro ${ }^{\mathrm{II}}$ \\ Eduardo Vieira Silveira ${ }^{\text {II }}$ Marcos Felipe de Castro Lourenço ${ }^{\text {III }}$
}

\begin{abstract}
Vegetable oils are suitable for human consumption as ABSTRACT part of a healthy diet and native fruits of the cerrado, such as almond baru, which are natural sources of these oils. This study informed about the quality of baru oil having as a basis for comparison, soybean oil and olive oil, usually consumed in human diet. Analyzes of acid value, peroxide and iodine for the three oils and fatty acid composition for the baru oil were performed according to official standard methodology. Baru oil has the potential to be part of the human consumption, in healthy diets similarly to soybean oil and olive oil.
\end{abstract}

Key words: cerrado, baru oil, vegetable oils, Dipteryx alata Vog.

RESUMO

Óleos vegetais são indicados na alimentação humana como parte de uma alimentação saudável. Parte dos frutos nativos do cerrado, como a amêndoa de baru, são fontes naturais desses óleos. Objetivou-se, com este estudo, informar a respeito da qualidade do óleo de baru, tendo como base de comparação o óleo de soja e o azeite de oliva, usualmente consumidos na alimentação humana. Foram realizadas análises de indice de acidez, peróxido e iodo segundo normas oficiais para todos os óleos e, para o óleo de baru, foi realizada ainda a composição em ácidos graxos, também segundo metodologia oficial. O óleo de baru tem potencial para fazer parte da alimentação humana em dietas saudáveis de forma similar ao óleo de soja e ao azeite de oliva.

Palavras-chave: cerrado, óleo de baru, óleos vegetais, Dipteryx alata Vog.

Vegetable oils are usually obtained from plant seeds and occasionally from fruit pulps. In recent decades, the market demand for vegetable oils from various natural sources has increased sharply, with emphasis on their application in food derivatives and in formulation of new products (CONCEIÇÃO et al., 2005). Fruits from Cerrado, such as buriti, baru and pequi have been regarded as important natural sources for extraction of vegetable oils, and are rich in lipids of good quality for human nutrition.

Among the most consumed vegetable oils, soy leads the world market. In Brazil, soybean oil accounts for over $50 \%$ of all oils and fats in food products and has a broad international market (ABIOVE, 2011). Similarly to that of soybean, olive oil, derived from the fruit of the olive tree also stands out for its global production and marketing, especially in Brazil. Olive oil is appreciated for its smooth flavor, distinct from other vegetable oils (NUNES et al., 2013).

Little known and exploited in Brazil, the oil from baru almond is usually extracted by regional cooperatives and contributes to the sustainability of the population of the Brazilian cerrado and it is currently exported to Germany. The oil has a high degree of unsaturation, relevant $\alpha$-tocopherol content. Oleic and linoleic acids are the main fatty acids in composition of the baru oil, and linoleic acid is considered essential, which favors its use for food purposes and as raw material for pharmaceutical and oleochemical industries (TAKEMOTO et al., 2011; SIQUEIRA et al., 2015).

\footnotetext{
IDepartamento de Tecnologia de Alimentos, Instituto Federal Goiano, Campus Morrinhos, 75650-000, Morrinhos, GO, Brasil. E-mail: siqueiracta@gmail.com. Corresponding author.

IIPrograma de Pós-graduação em Agroquímica, Instituto Federal Goiano, Rio Verde, GO, Brasil.

IIIDepartamento de Agronomia, Instituto Federal Goiano, Urutaí, GO, Brasil. Received 03.31.15 Approved 03.18.16 Returned by the author 06.14.16 CR-2015-0468.R3
} 
This study is justified considering the importance of baru oil to the sustainability of the Brazilian cerrado and the scarce knowledge about this product compared to soybean and olive oils, which are widely used in the human diet. This research aimed to inform about the quality of baru oil compared to soybean and olive oils.

The commercial soybean oil and the extra virgin olive oil were purchased at a local market in the city of Rio Verde, GO. The baru oil was extracted via cold pressing in a hydraulic oil press machine (Caver Laboratory Press, model C, No. 24000-415 series) and analyzed as crude.

Oils were analyzed for acidity, peroxide and iodine indexes, by titration in triplicate, according to official methodology, described by the Adolfo Lutz Institute (IAL, 2008). Fatty acid content was determined by gas chromatography according to AOCS Ce 1a-13 (FIRESTONE, 2014). This analysis was performed only for baru oil, since for the other oils, sufficient data are found in the literature for comparison. The results of chemical analysis were submitted to analysis of variance (ANOVA) and the means compared by Tukey test at $5 \%$ probability.

Tocopherols and carotenoids were determined for Baru oil sample used in this study and the results were published by SIQUEIRA et al. (2015) which reports $11.61 \pm 0.08\left(\mathrm{mg} 100 \mathrm{~g}^{-1}\right)$ tocopherols, the most significant being the $\alpha$-tocopherol and $11.40 \pm 0.40\left(\mu \mathrm{g} 100 \mathrm{~g}^{-1}\right)$ of carotenoids in this oil.

In a study with vegetable oils, GUINAZ et al. (2009) recommended $15 \mathrm{mg}$ of $\alpha$-tocopherol day1 and state that soybean oil and olive oil contribute significantly to the daily intake of vitamin E. As the above oils, small amounts of baru oil also supply the daily need of vitamin E. The baru oil; although, showing intense yellow coloring, have low carotenoid content compared to other vegetable oils, for example soybean, corn and canola oils.

Low acidity index of the vegetable oils and the extra virgin olive oil (Table 1) shows that these were derived from a good quality raw material and processing (MELLO \& PINHEIRO, 2012). Acidity index of the baru oil (Table 1), even crude, was low and close to the values observed in refined and processed commercial oils, constituting a significant parameter of its high quality. The importance of this parameter is justified because the baru oil is traditionally used in raw state in the local culinary of the Cerrado region. The baru oil, due to the similarity to the peanut oil in chemical constitution and by not having specific legislation, can be compared by physicochemical parameters with peanut oil as established by the RDC law No. 482 of 1999 (BRASIL, 1999).

The baru oil had adequate peroxide content (Table 1) according to the Brazilian RDC law No. 270 of 2005 that reports $15 \mathrm{meq} \mathrm{kg}^{-1}$ oil for crude oils (BRASIL, 2005). This index expresses the initial oxidation state of vegetable oils and also indicates deterioration which might have undergone certain nutritional components of interest, such as vitamin E (MELLO \& PINHEIRO, 2012). This parameter is important because it reflects that the cold extraction process of the oil does not compromise the quality of the product without causing oxidation. The peroxide index of the crude baru oil was very close to that of soybean oil and olive oil, products processed commercially.

The baru oil presented iodine index very similar to that of the extra virgin olive oil (Table 1). Iodine index measures the degree of unsaturation of fatty acids present in the samples and also enables the

Table 1 - Fatty acid profile and physicochemical characteristics of baru oil, soybean oil and extra virgin olive oil (EV).

\begin{tabular}{|c|c|c|c|}
\hline \multirow{2}{*}{ Fatty acids } & \multirow[b]{2}{*}{ Baru oil } & \multirow[b]{2}{*}{ EV olive oil ${ }^{*}$} & \multirow[b]{2}{*}{ Commercial soybean oil ${ }^{* *}$} \\
\hline & & & \\
\hline Palmitic & $6.4 \pm 0.14$ & 10.8 & 11.0 \\
\hline Estearic & $3.9 \pm 0.14$ & 3.8 & 4.0 \\
\hline Oleic & $49.2 \pm 0.005$ & 69.5 & 23.4 \\
\hline Linoleic & $27.3 \pm 1.20$ & 14.9 & 53.2 \\
\hline Linolenic & $4.2 \pm 0.07$ & 0.6 & 7.8 \\
\hline Acidity index (mg KOH g ${ }^{-1}$ oil) & $0.28 \pm 0.05^{\mathrm{a}}$ & $0.22 \pm 0.05^{\mathrm{a}}$ & $0.04 \pm 0.01^{b}$ \\
\hline Peroxide index (meq $\mathrm{O}_{2} \mathrm{~kg}^{-1}$ oil) & $1.61 \pm 0.05^{\mathrm{c}}$ & $6.39 \pm 0.34^{\mathrm{a}}$ & $2.19 \pm 0.14^{\mathrm{b}}$ \\
\hline Iodine index ( $\mathrm{g} \mathrm{I}_{2} 100 \mathrm{~g}^{-1}$ oil $)$ & $72.9 \pm 2.2^{\mathrm{b}}$ & $71.4 \pm 2.9^{\mathrm{b}}$ & $83.1 \pm 12.4^{\mathrm{a}}$ \\
\hline
\end{tabular}

\footnotetext{
*Source: USDA National Nutrient Database for Standard Reference (UNITED STATE DEPARTMENT OF AGRICULTURE, 2005).
}

${ }^{* *}$ Source: FUENTES, $2011^{\mathrm{a}, \mathrm{b}, \mathrm{c}}$ same letters on the same line do not differ significantly by the Tukey test at $5 \%$ probability. 
identification of possible adulteration by mixing with different vegetable oils (CODEX ALIMENTARIUS, 2003; MELLO \& PINHEIRO, 2012).

This unsaturation level can be observed when analyzing the composition of fatty acids in baru oil (Table 1), which is rich in monounsaturated and polyunsaturated components. This oil is constituted of about $50 \%$ of oleic acid and a significant proportion of linoleic acid, similar to that found in the literature, with about $80 \%$ of unsaturation (FREITAS \& NAVES, 2010).

According to ANGELIS (2001), many studies have confirmed the beneficial effects of olive oil consumption in the effective reduction of oxidation of LDL-cholesterol, attributed to its content of oleic acid, around $70 \%$. Baru oil contributes with $50 \%$ oleic acid (Table 1). Besides, linoleic acid present in baru oil composition in reasonable amounts (Table 1), is considered essential in human nutrition and; therefore, this observed content can stimulate the use of baru oil in healthy diets.

The baru oil has a significant content of total tocopherols (vitamin E) and desirable fatty acid composition from a nutritional point of view. It does not oxidize with the cold extraction process and have similar coloration in relation to other studied oils. This oil has already been used in regional culinary, in some places in the cerrado. However, baru oil used as raw or as an ingredient has the potential to be disseminated, becoming part of the diet in other regions of Brazil and other countries, contributing to the sustainability of the cerrado.

\section{REFERENCES}

ABIOVE (BRAZILIAN ASSOCIATION OF VEGETABLE OILS INDUSTRIES). Coordinating body of economics and statistics. Available from: <http://www.abiove.com.br/balanco_br.html $>$. Accessed: Feb. 25, 2015.

ANGELIS, R.C. New concepts in nutrition: considerations on the connection diet-health. Archives of Gastroenterology, v.38, n.4, p.269-271, 2001. Available from: <http://dx.doi.org/10.1590/ S0004-28032001000400010>. Accessed: Mar. 13, 2015. doi: $10.1590 /$ S0004-28032001000400010

BRASIL. Laws, decrees, etc. Resolution No. 482 of 23 September 1999, the National Health Surveillance Agency of the Ministry of Health. Approves the Technical Regulation on Vegetable Fats and Oils. Official Gazette, Brasilia, 13 Oct. 1999, Section I, p.82-87, (Anex 3 - Peanut oil).
BRASIL. Health Surveillance. Resolution RDC n. 270, September 22, 2005. Provides for technical regulation for vegetable oils, vegetable fats and vegetable cream. Official Journal of the Federative Republic of Brazil, Brasilia 23 Sept. 2005, section 1, no. 184.

CODEX ALIMENTARIUS COMMISSION. Codex standards for olive oils and olive pomace oil: CODEX STAN 33-1981 (rev. 2-2003). Rome: FAO/WHO, 2003. 9p.

CONCEIÇÃO, M.M. et al. Rheological behavior of Castor oil biodiesel. Energy \& Fuels, v.19, n.5, p.2185-2188, 2005. Available from: <http://dx.doi.org/10.1021/ef050016g >. Accessed: Mar. 13, 2015. doi: 10.1021/ef050016g.

FIRESTONE, D. (Ed.). Official methods and recommended practices of the American Oil Chemists Society. 6.ed. 3.print. Urbana: AOCS 2014. Met. Ce 1a-13.

FREITAS, J.B.; NAVES, M.M.V. Chemical composition of nuts and edible seeds and their relation to nutrition and health. Revista de Nutrição, v.23, n.2, p.269-279, 2010. Available from: <http:// www.scielo.br/pdf/rn/v23n2/v23n2a10.pdf>. Accessed: Feb. 23, 2015. doi: $10.1590 / \mathrm{S} 1415-52732010000200010$.

FUENTES, P.H.A. Evaluation of quality of soybean, canola, corn and sunflower oils during storage. 2011. Total de folhas? (Master's Dissertation) - Federal University of Santa Catarina, Brazil).

GUINAZ, M. et al. Tocopherols and tocotrienols in vegetable oils and eggs . Química Nova, v.32, n.8, p.2098-2103, 2009. Available from: <http://dx.doi.org/10.1590/S0100-40422009000800021>. Accessed: Jul. 10, 2015. doi: 10.1590/S0100-40422009000800021.

IAL (INSTITUTO ADOLFO LUTZ). Normas analíticas do instituto Adolfo Lutz. 4.ed. São Paulo, 2008.1000p.

MELLO, L.D.; PINHEIRO, M.F. Physico-chemical characterization of monovarietal olive oil and olive leaves of cultivars introduced in the RS State, Brasil. Alimentos e Nutrição, v.23, n.4, p.537-548, 2012.

NUNES, C.A. et al. Heating on the volatile composition and sensory aspects of extra-virgin olive oil. Ciência e Agrotecnologia, v.37, n.6, p.566-572, 2013. Available from: <http://dx.doi.org/10.1590/ S1413-70542013000600010>. Accessed: Mar. 13, 2015. doi: 10.1590/S1413-70542013000600010.

SIQUEIRA, A.P.S. et al. Nutritional quality and bioactive compounds of partially defatted baru almond flour. Ciência e Tecnologia de Alimentos, v.35, p.127-132, 2015. Available from: $<$ http://dx.doi. org/10.1590/1678-457X.6532>. Accessed: Mar 13, 2015.

TAKEMOTO, E. et al. Chemical composition of seed and baru oil (Dipteryx alata Vog.) native of the City of Pirenopolis, State of Goias . Revista do Instituto Adolfo Lutz, v. 60, n.2, p.113-117, 2001.

USDA. National nutrient database for standard reference. 2005. Release 18. Nutrient Data Laboratory. Available from: $<$ http:// www.ars.usda.gov/ba/bhnrc/ndl>. Accessed: Mar. 13, 2015. 